\title{
TCOM \\ The COVID-19 mirror: reflecting science-society relationships across 11 countries
}

\author{
Jenni Metcalfe, Michelle Riedlinger, Martin W. Bauer, \\ Anwesha Chakraborty, Toss Gascoigne, Lars Guenther, \\ Marina Joubert, Margaret Kaseje, Susana Herrera-Lima, \\ Gema Revuelta, Jan Riise and Bernard Schiele
}

\begin{abstract}
Twelve researchers from 11 countries used autoethnographic techniques, keeping diaries over 10 weeks of the COVID-19 crisis, to observe and reflect on changes in the role and cultural authority of science during important stages of viral activity and government action in their respective countries. We followed arguments, discussions and ideas generated by mass and social media about science and scientific expertise, observed patterns and shifts in narratives, and made international comparisons. During regular meetings via video conference, the participating researchers discussed theoretical approaches and our joint methodology for reflecting on our observations. This project is informed by social representations theory, agenda-setting, and frames of meaning associated with the rise and fall of expertise and trust. This paper presents our observations and reflections on the role and authority of science in our countries from March 10 to May 31,2020 . This is the first stage of a longer-term project that aims to identify, analyse and compare changes in science-society relationships over the course of the ongoing COVID-19 pandemic.
\end{abstract}

Keywords

DOI

Public engagement with science and technology; Representations of science and technology; Risk communication

https://doi.org/10.22323/2.19070205

Submitted: 29th June 2020

Accepted: 21st September 2020

Published: 14th December 2020

Introduction

The global COVID-19 pandemic put a spotlight on science and brought about an intense focus on the relationship between science and society. Mass and social media have provided public access to COVID-19 (research) information, enabling people to consider the role and authority of science and to debate the implications of policies and regulations. COVID-19 has made it possible to track and document the dynamic, intense and multifaceted societal conversations about science taking place around the globe. 
A global pandemic is not an event that elicits fixed reactions; more likely it triggers diverse responses based on local circumstances and cultural memory similar to responses to a major disaster [Bauer, Gylstorff et al., 2019]. This article reports the experiences of 12 researchers from 11 countries: Australia, Canada, Germany, India, Italy, Kenya, Mexico, South Africa, Spain, Sweden, and the United Kingdom. Researchers kept their own diaries of local observations from their "media diet" and notes from conversations with friends, family and colleagues, often under restricted movement conditions. We individually tracked the science communication actors, themes, and issues appearing in media reporting and on social media platforms from March 10 to May 31, 2020 as the pandemic moved from China to Europe, and then to Africa and the Americas. Our study focusses on the ways scientific advice on the containment and treatment of COVID-19 unfolded and changed. We aim to identify changes in science-society relationships as key messages and perceptions of the cultural authority of science and scientists developed globally.

Long before COVID-19, many governments and health agencies had been planning for a widespread pandemic [Smith, 2006; Holmes et al., 2009; Collinson, Khan and Heffernan, 2015] in response to long-standing warnings [Garrett, 1994].

Recommendations stressed the need for transparent and timely public communication by experts in partnership with the mass media to enlist public support for collective action. Following influenza-type outbreaks over the last 20 years, science communication researchers have studied relevant mass media reporting and its implications intensively [e.g., Dudo, Dahlstrom and Brossard, 2007; Sandman, 2009; Hilton and Smith, 2010; Fogarty et al., 2011; González, Hoyos and Méndez, 2011; Mandeville et al., 2014; Collinson, Khan and Heffernan, 2015]. At the same time, a body of knowledge has emerged related to the sociology of pandemics, focussing on how societies respond to pandemics and the consequences of these responses. According to Dingwall, Hoffman and Staniland [2013], pandemics offer researchers the opportunity to identify features of science-society relationships often only visible in times of crisis. As the global COVID-19 pandemic unfolded, science communicators had unique opportunities to witness the inherently dynamic and unpredictable nature of a public health crisis as it was reported and debated in media around the world.

Despite a changing communication landscape, traditional media outlets have remained a major source of information for many people due to its perceived credibility during a crisis [Austin, Fisher Liu and Jin, 2012; Bucchi and Saracino, 2020]. Major policy decisions, and the scientific rationales for these decisions, are announced and interpreted by the media, providing a daily (if not hourly) chronicle of events and debates. People access information through mass media to assess risks and protect themselves. However, media content also shapes public opinion about the implications of the pandemic. People turn to Twitter, Facebook, Instagram and WhatsApp to share content, to gather news, information and opinions, and to participate in societal conversations [Anderson, Brossard and Scheufele, 2010; Brossard, 2013; Brossard and Schefeule, 2013]. Media provide a rich archive that we can investigate to better understand how science is communicated and debated, and how media stories are amplified through various social media channels. 
Media reporting and online discussions of the pandemic and policy responses make the political nature of science (and science communication) visible. Reporting and discussions provide an opportunity for a novel case study of what Scheufele [2014] refers to as science communication as political communication. According to Bauer, Pansegrau and Shukla [2018], society's goodwill can decline over specific scientific issues that are highly politicised. The cultural authority of science may remain high overall for a nation, but may be in jeopardy on a particular issue or with a particular sector of society. In nations where the general goodwill towards science is low, some areas of science or individual scientists may experience irreparable damage. Disciplinary or professional reputations can be jeopardised when scientists express views that clash with others on controversial or politicised issues. Bauer, Pansegrau and Shukla [2018] suggest that this dynamic can help explain the reluctance of some researchers to participate in public debate, on the grounds it may be reputationally risky. Following this logic, the COVID-19 pandemic can be seen as a scientific issue affecting the cultural authority of science and the willingness of scientists to engage in public communication, which could also be understood as political communication.

The information collected by the 12 researchers involved in this study provides us with contextual data for a subsequent thematic mapping of media content in later stages of this project. The team, who were all present within their own countries (with the exception of India where the researcher was in close contact with family, friends and media in India) met fortnightly via Zoom to discuss diary content and to reflect on individual observations. It was during these discussions that our approaches to the research emerged. We agreed to focus on six research questions and common points of reference, but we all took our own approaches to the task of recording. The paper reflects this diversity of national panoramas.

The next sections in this paper describe the theoretical approaches and the methods based on autoethnographic techniques that we used in this project. Our observations start on March 10, 2020 (the day before the World Health Organisation declared COVID-19 as a global pandemic) and end on May 31, 2020, thereby covering 10 weeks during which the pandemic spread across the globe. This paper covers the time period from the identification of first infection to the time when the rate of infections started to decline in some countries and traces this period in media messaging implicating science communication. In our Zoom meetings, we identified a number of common themes emerging from these observations. In this paper, we reflect on these common themes, and examine similarities and differences across countries.

Theoretical approaches
While individually keeping and collaboratively discussing the diaries, we identified three key theoretical approaches that helped us to better understand the events and the discourses we observed in our individual media diaries. All three approaches address the questions: what does the virus mean in different places and how does this change over time? Firstly, social representations theory (SRT) [Moscovici, 1961; Bauer and Gaskell, 1999; Wagner and Hayes, 2005; Andreouli, Gaskell and Valsiner, 2015; Franks, Bangerter and Bauer, 2013] helped us understand communicative responses to new and potentially threatening events involving expert information. Social representations mobilise existing behaviours, opinions, images and beliefs that render a novel event familiar and thus less 
threatening. Communities work to maintain a cohesive world view by using familiar terms to name events, thereby reducing the perception of a threat or making it comprehensible. For example, naming a novel virus as the 'Wuhan virus' or viewing COVID-19 as a foreign invasion that requires a warfare response, illustrates this process of meaning-making called "anchoring" [Sammut et al., 2015, p. 361]. People make abstract ideas more concrete using metaphors and visualisations. For example, efforts to reduce viral infection numbers in the population through social distancing and quarantine measures are referred to as "flattening the curve". This process is described as "objectifying", an approach ripe with iconoclastic doubts [Bauer, 2015].

Secondly, we recognised agenda-setting in shaping joint attention within the public sphere and steering the thematic flow of public opinion. Agenda-setters [see McCombs and Shaw, 1972] draw attention to specific opinions through media outlets and platforms. Mass media contribute to agenda-setting by affording prominence and salience to certain topics and actors [McCombs, 2004; Allgaier, 2011; Gugsa et al., 2016]. On social media, agenda-setting mostly takes place without editorial or journalistic gatekeeping. Some argue that social media platforms can concentrate unfiltered, false, or potentially damaging information and opinions [German National Academy of Sciences, 2017; Gottlieb and Dyer, 2020]. Researchers have found that COVID-19 mis- and disinformation on Twitter often originates in politically-motivated communities concerned about other issues, such as the impacts of 5G mobile technologies, vaccine technologies, and the global influence of China; this mis- and disinformation circulate more widely in times of crisis [Graham et al., 2020]. The Director-General of the World Health Organisation (WHO) has labelled this issue an 'infodemic' to draw greater public attention to it [United Nations Department of Global Communications, 2020]. In terms of agenda-setting, we documented and tracked public attention on science and society-related themes and topics, and their roles in bringing visibility and influence to certain actors.

Finally, we looked at how these science-society themes emerged and receded, and aligned with particular frames of meaning [e.g., Entman, 1993; Franzosi and Vicari, 2018]. Framing devices make audiences more likely to be persuaded by specific arguments. A news topic can be framed to either encourage agreement or encourage criticism of a specific scientific finding, political announcement or legal regulation. For example, stringent restriction of community movement during a pandemic can be presented as an evidence-based health intervention to save lives, or as an economic burden that exacerbates unemployment and poverty. In our individual and collaborative reflections, we looked for trends in aligned episodic news-framing (i.e., trends in reporting and posting related to single, specific event-driven topics), and thematic news-framing (i.e., trends posting related to a series of topics relevant to an overriding issue), on both traditional media and social media, to determine how COVID-19 has been represented.

Autoethnography pooled
Under COVID-19 circumstances, the researchers involved in this project were confined to their homes or restricted from travelling to various degrees. This made employing autoethnographic techniques useful for gathering data: each of us bears witness to the events from within local restrictions. We were interested in tracking the initial phase of the pandemic across different countries, providing event-based 
snapshots and reflections of how science entered public conversations around the virus. As scholars have articulated, methods using autoethnographic techniques aim to challenge detached, often stereotypical, narratives about places and cultures and to provide witness accounts about, e.g. the public experience of COVID-19, which can complement existing knowledge and research gaps [Adams, Ellis and Jones, 2017].

We are aware that methods using autoethnographic techniques challenge naïve notions of scientific objectivity, data quality and legitimacy, because the researchers themselves are the instrument, not the neutral reporters of instruments [Wall, 2008]. We triangulated our observations with a variety of media: traditional, social and digital media attention (see Table 1 for media sources) combined with conversations with people in our everyday lives. At the same time, the news we read and engaged with stimulated our individual reflections on the unfolding narrative of the pandemic.

Our methods included qualitative daily record taking, described by Patterson [2005, p. 142] as "an innovative way to capture rich insights" by recording personal witness accounts of events, observations and thoughts. Diaries are valuable tools for capturing and encouraging reflective thinking. They offer rich data of self-observation and introspection [Hewitt, 2017]. Pandemics have generated genres of writing of personal experience, famuously the 'Wuhan Diaries' by writer Fang Fang [2020], or earlier, Albert Camus' famous 'La Peste (The Plague)' [1947]. However, the diaries of this project are less introspective and closer to ethnographic field notes [Bryman, 2012]. Given that our diaries are first-hand accounts, that we used to identify similar and different patterns across diaries, we created a collective or pooled account using autoethnographic techiques that was event-based and reflexive [Bryman, 2012].

The aim of methods using autoethnographic techniques is to understand locally conditioned responses to events by recording, describing and comparing personal experiences [Ellis, Adams and Bochner, 2011], which is exactly what our group did. According to Adams, Ellis and Jones [2017], who tracked the history of autoethnography as a method, it was in the 1990s that the term came to mean the use of personal experiences and reflections to discuss and examine cultural experiences. For Lapadat [2017, p. 589], autoethnography is an approach "in which a researcher recounts a story of his or her own personal experience, coupled with an ethnographic analysis of the cultural context and implications of that experience." By combining and comparing personal observations across a team of researchers, this project created a collaborative, pooled account using autoethnographic techniques [Lapadat, 2017]. The diaries were structured, solicited, and completed with a focus on streams of events [Kenten, 2010] that we agreed to record after initial project meetings. We recorded the COVID-19 outbreak through a science-society lens, over an extended period, maintaining field notes, and in conversation with family members and friends, which is commonly done in autoethnography [Adams, Ellis and Jones, 2017].

Through our discussions, we realised that our diaries dealt with several time clocks. Firstly, there was the spread of the virus in the global pandemic (the 'global (lock'). We approached this project from an understanding that COVID-19 may be one of the first events to create global public opinion by synchronising all public 
spheres to the same focus of attention. Secondly, the virus arrived in each country at a different time (the 'inner or local clock'), rising and reaching peak caseloads and (in most countries) eventually retreating (see Figure 1 below). Thirdly, governments responded to national pandemic conditions with official announcements and interventions (the official 'local action clock'). The fourth clock is the timing of public discourse and its characteristic thematic flow (the 'public discourse clock'). The empirically-derived fourth clocks for each country are the focus of our pooled observations and the synthesis thereof in this paper. We explore how these different chronologies go together. Each researcher recorded key actors, themes, topics, and issues relating to how the COVID-19 pandemic unfolded in each country. These observations were individually summarised and informed by the theoretical approaches presented earlier in this paper: social representation theory, agenda setting, and frames of meaning. Individual summaries included references to particularly illustrative media accounts.

It is important to emphasise that this paper provides a synthesis of the main science-society themes, who conveys these themes, how these themes are debated, and how they change over time. The researchers accessed their sources listed below to compile their diaries.

Table 1. Media sources according to countries.

\begin{tabular}{|c|l|}
\hline Country & Media reviewed \\
\hline Australia & $\begin{array}{l}\text { The Guardian, Australia; The Conversation, Australia; Sydney Morning Herald; } \\
\text { The Brisbane Times; ABC - radio / online / TV; Twitter }\end{array}$ \\
\hline Canada & Ici Radio-Canada; CBC News; Le Devoir; La Presse; The Globe and Mail \\
\hline Germany & $\begin{array}{l}\text { Der Spiegel (online); ARD-Tagesschau (TV and online); Facebook; Instagram; } \\
\text { WhatsApp }\end{array}$ \\
\hline India & $\begin{array}{l}\text { The Hindu; NDTV; Anandabazar Patrika; Facebook: specifically, social media pages } \\
\text { of ministers, administrators and health experts; WhatsApp; international press } \\
\text { coverage }\end{array}$ \\
\hline Italy & $\begin{array}{l}\text { La Repubblica and La Stampa; Facebook; Twitter; TV; government press releases; } \\
\text { public health authorities' website }\end{array}$ \\
\hline Kenya & $\begin{array}{l}\text { Daily Nation; The Standard; The East African; Kenya Times; Citizen TV; NTV; KTN, } \\
\text { Kenya Broadcasting Corporation; government press releases, WhatsApp }\end{array}$ \\
\hline Mexico & $\begin{array}{l}\text { Government press releases; coronavirus.gob.mx; La Jornada; El Universal; Milenio; } \\
\text { CNN en español; WhatsApp and Facebook }\end{array}$ \\
\hline $\begin{array}{l}\text { South } \\
\text { Africa }\end{array}$ & $\begin{array}{l}\text { Newws2; IOL; Daily Maverick; Business Day; The Conversation Africa; EWN; TimesLive; } \\
\text { Bhekisisa Health Journalism Centre, Mail E Guardian; New Frame News; Facebook; } \\
\text { Twitter; eNCA Television News; Cape Talk; government press releases }\end{array}$ \\
\hline Spain & $\begin{array}{l}\text { TVE1; TV3; La SER; El País; La Vanguardia; El Mundo; Diario.es; Huffington Post; } \\
\text { The Conversation Spain; Maldita.es; Civio; Twitter }\end{array}$ \\
\hline Sweden & $\begin{array}{l}\text { Ny Teknik; Dagens Nyheter; Expressen; Aftonbladet; Hallandsposten; Public service } \\
\text { online: sverigesradio.se; svt.se }\end{array}$ \\
\hline $\begin{array}{l}\text { United } \\
\text { Kingdom }\end{array}$ & $\begin{array}{l}\text { BBC Radio 4; Twitter; Weekend newspapers; press cuttings; Daily TV evening news } \\
\text { BBC, ITV, occasionally EuroNews, Al Jazeera }\end{array}$ \\
\hline
\end{tabular}


The 'internal clock' for the virus
Our diaries corresponded to the four stages that we refer to as the internal virus clock for each country:

1. The first 100 infections identified

2. Infections and death numbers rise

3. The curve "flattened"

4. Decreasing cases, with curve bending downwards.

Figure $1^{1}$ represents daily new confirmed COVID-19 cases from March 10 to May 31, 2020 (Source of data: Our World in Data). The Y-axis data are displayed on a logarithmic scale (this allows countries with few cases and those with many cases to be shown on the same graph). Each subfigure (1a, $1 b$ and $1 c)$ represents a group of countries with a similar 'internal virus clock'. Figure 1a includes those countries that, at May 31, continued to show a clear increasing trend in daily new confirmed COVID-19 cases (India and Mexico) or had not yet confirmed they had arrived at the maximum peak of cases (South Africa and Kenya). So, countries in Figure 1a have passed Stage 1 of the internal virus clock and, as of May 31, were at Stage 2. Figure $1 \mathrm{~b}$ includes countries reflecting they were "flattening the curve" as of May 31 (Canada, Sweden, and the U.K.) (Stage 3). Figure 1c includes countries with decreasing COVID-19 infection rates as of May 31 (Australia, Germany, Italy and Spain).

In this paper, we discuss the restrictions that various governments imposed to control the spread of the virus. Many countries introduced a set of restrictions on social movements and economic activities, commonly referred to as "lockdown". However, the conditions of lockdown varied from country to country (or even regions within a country) and changed over time. For example, in South Africa most businesses and schools were shut down and there were strict curfews and restrictions imposed (including a total ban on the sale of alcohol and tobacco products). In Germany, schools and kindergardens were closed, followed by public parks and (major) stores. Then, as these restrictions were eased, masks were mandatory in shops and on public transport. By contrast, Sweden did not impose a lockdown, but did impose restrictions on public gatherings, initially limited to 500 persons, which was later reduced to 50 . Due to these significant variations, we have focussed our discussions on the media and scientific discourses around physical and social restrictions, rather than how and when lockdowns were imposed.

Our team met fortnightly over the research period jointly to reflect on our individual diaries. Through our discussions, we identified six overall research questions that helped us to focus our observations on the science communication aspects that emerged in media and public discourses. These six questions reflect the three theoretical approaches we outlined above:

Q1: What are the main science communication themes being conveyed about the pandemic and how did these change over time? (all three theoretical approaches)

\footnotetext{
${ }^{1}$ The few small gaps in these line graphs are the result of data gaps in the data set from 'Our World in Data', due to the fact that some governments detected errors in their case numbers.
} 
Figure 1a

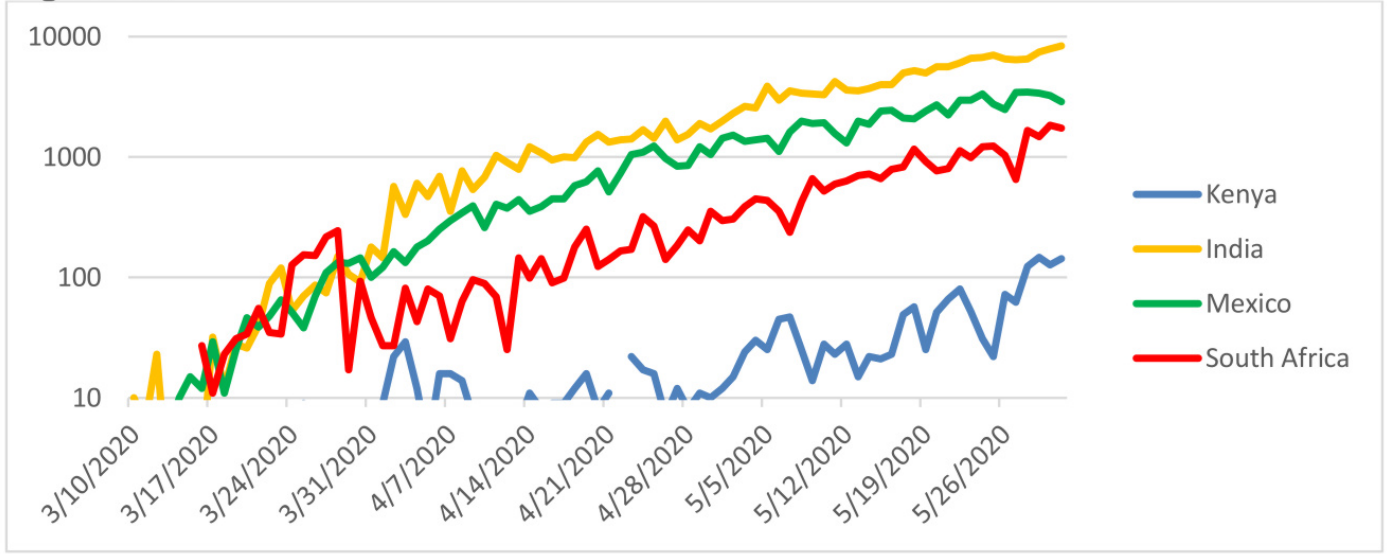

Figure $1 b$.

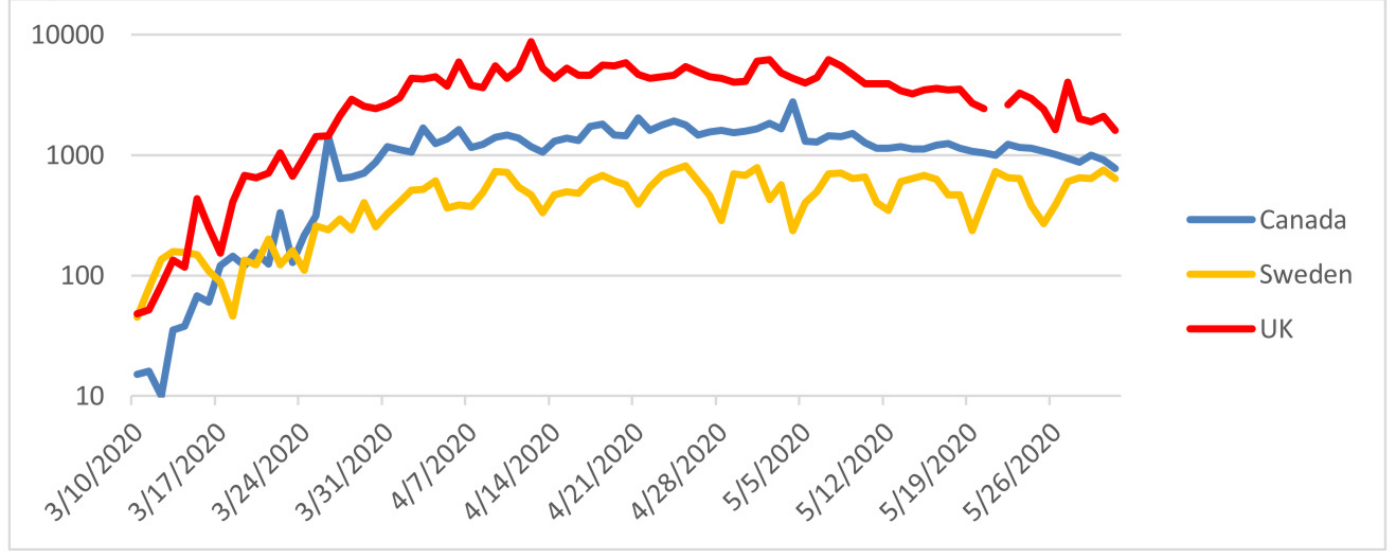

Figure 1c.

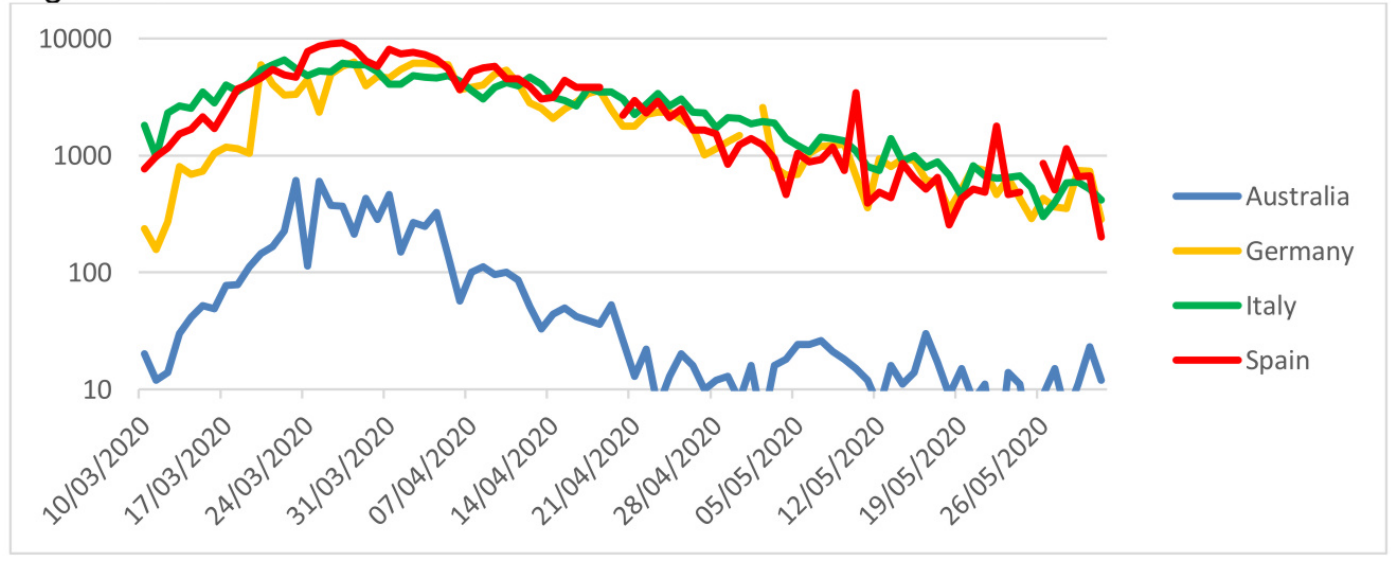

Figure 1. Logarithmic scale visualisation of daily new confirmed COVID-19 cases from 10/03/2020 to 31/05/2020. Figure 1a: India, Kenya, Mexico, and South Africa. Figure 1b: Canada, Sweden, and the U.K. Figure 1c: Australia, Germany, Italy, and Spain. (Source of data: Our World in Data).

Q2: Who are the COVID-19 science communicators? (agenda setting)

Q3: What are the (shifting) debates about science? (all three theoretical approaches)

Q4: What indications are there of people's attitudes to science and scientists? (frames of meaning) 
Q5: What conspiracy theories and misinformation are circulating? (all three theoretical approaches)

Q6: What appears to be unique about the science coverage to each country? (all three theoretical approaches).

In writing this paper, we empirically mapped the four stages of the 'internal clock' to four phases of media communication that we jointly considered were relevant to the COVID-19 crisis: (a) public concerns increasing; (b) attempts and policies to flatten the curve through physical and/or social restrictions; (c) the impact of restrictions on citizens; and (d) discussions after the first infection curve flattened about ongoing restrictions, changes to society, and a possible second wave of infections. Two of the authors synthesised the individual reflections and then the group discussed and added to this synthesis.

In summary, to create a pooled account based on data collected using autoethnographic techniques over three months during the pandemic of 2020, we firstly, recorded first-hand accounts of science-society interactions unfolding in the media (March 10-May 31, 2020). Secondly, we jointly discussed our individual observations and empirically agreed on the stages of the 'internal' virus clock and the four phases of media communication. Thirdly, we individually mapped our own observations according to the internal virus clock and phases of media communication. Fourthly, we individually summarised our reflections according to the three theoretical approaches, identifying illustrative media references. Finally, we synthesised individual mapping and reflective summaries under the six questions, as summarised in the rest of this paper.

\section{Q1: Main science themes over the four phases}

Phase 1: rising infections and concerns. As infections and concerns rose in each country, we identified an overall preventative theme that included the need for personal hygiene and physical distancing to reduce the spread of infections. Italy led the way after experiencing a rapid escalation of infections and high mortality rates. Italy was closely followed by Spain and (comparing countries with countries, regions with regions) became the centre of the debate.

For most countries, symptoms of infection (itchy throat, a dry cough and then fever) were standardised and widely reported in different media. The emphasis was on informing the population with the best scientific evidence available.

Phase 2: attempts and policies to flatten the curve. With rising global concern and media commentary provided by a range of experts from diverse disciplines (e.g. in epidemiology, immunology, infectious diseases, and public health), the media communication for all countries focussed on "flattening the curve" and, in most cases, the need for government policies and action. The visual representation of the infection as a curve attempted to make the threatening and unfamiliar more familiar. It also sought to reinforce the need for action and the positive impacts of preventative measures.

An initial agreement between politics and science characterised the action regarding the pandemic in many countries. In Italy, a nationwide lockdown 
happened two days before the WHO announced a pandemic (March 11), with the decree "Io resto a casa" (I will stay home). This lockdown was extended to mid-April after the infection peak had been reached and rates of infection were declining. The prime minister and executive branch wanted to maintain caution, in line with the expert advice they were receiving. In Germany, Chancellor Angela Merkel repeatedly emphasised the advice given by scientists working, for example, at Robert Koch Institute in Berlin and the German National Academy of Sciences Leopoldina in Halle/Saale. When she addressed the nation - for the first time in her 14 years in office other than her annual New Year's address - she reminded Germans of what they could do to help slow the spread of the virus (i.e., flattening the curve). She again emphasised the importance of basing decisions on advice from scientists.

By contrast, Indian Prime Minister Narendra Modi's speeches were almost completely devoid of scientific information, but he continued to enjoy very high approval ratings amongst his electorate. International media and sections of national media were more critical of the planning of the nationwide lockdown which Modi announced on 24 March. The lockdown was to be effective immediately and would last the next 21 days, thereby giving India's vast population a period of just four hours to organise their lives. Images of migrant labourers leaving big cities because of lost livelihoods were widely reported in the news and shared on social media.

In Sweden, the government chose not to order a complete lockdown, consistent with an implied policy of letting 'herd immunity' emerge. This decision was based on scientific advice, reflecting partly Swedes' general trust in government agencies and rules, partly that the evidence at the time in favour of a lockdown was quite weak. The rationale for keeping the country open was then to some extent that people were expected to wash their hands and keep their distance anyway.

Media use of metaphors was common, to explain the issue and make the unfamiliar more familiar, controllable and less threatening. The metaphor of cruise ships and planes being "petri-dishes" of infection pervaded Australian commentary. Cruise ships were a primary source of COVID infections in Australia, with untested and discharged passengers from one such ship (the Ruby Princess) being responsible for $20 \%$ of the total COVID deaths in Australia. In Canada, contaminated cruise ship travellers were forbidden from leaving their ships, which increased media coverage of the COVID-19 risks. In Kenya, some rural communities referred to the virus as "Akori (Corona) Daughter of China" and asserted that she was not allowed into their community since there had been no marriage negotiations. Media commentary during this period compared the virus infection to the usual annual common flu that came with the heavy rains and would soon disappear as dry weather set in. In South Africa, where lockdown was implemented early in the trajectory of infections, the community spread of COVID-19 was often compared to little fires that had to be stamped out before they became raging wildfires.

With efforts to flatten the curve came various appeals for scientific evidence, where science and political themes overlapped. In Canada, the dominant theme observed was that the collective good takes precedence over individual freedoms. Other scientific topics explored in the media during this phase were: the creation and timing of vaccines; possible cures; explaining the curve; the efficacy of masks for 
the general population; how many people should be tested and when; and ways to track the spread of infections. Questions of civil rights were raised, and debates on the effect on national economies began.

COVID-19 was also compared to past epidemics and pandemics. In Kenya, rural elderly community members recalled other epidemics in their lifetimes, including smallpox, HIV and AIDS. "We must act now or face calamity" was the rallying cry in the media and in social conversations. Similarly, South Africa moved rapidly to lockdown due to fears about the devastation COVID-19 could wreak on over-crowded informal settlements where many inhabitants already battled immune-compromising conditions such as HIV / AIDS and TB. The high rates of poverty in Mexico (50\% of the population), combined with high rates of obesity and diabetes were a potentially devastating combination; even young people might be infected. Health officials in Mexico made arguments based on this evidence to explain high death tolls.

A common media metaphor associated with science communication about lockdowns and curfews was one of war. In Kenya, health workers were recognised as "front-line soldiers" while being at high risk of infection. Experts braced themselves for a health crisis over limited hospital beds and ventilators, while preventive measures were described as a "war" that would be won through persuasion and community support, but not by guns. In the United Kingdom (U.K.), a "Dunkirk spirit" was invoked to mobilise laboratories across the country to increase their testing capacity. A forceful declaration of war on the coronavirus was prominent in the response of the South African government, and the country deployed its armed forces to ensure compliance with lockdown regulations. However, in Sweden, where there is no modern history of war, this metaphor was not used. In Mexico, this metaphor was also not used given its association with the fight against organised crime.

Phase 3: impacts of lockdown restrictions. As the curve was flattened or "bent" in some countries, or after prolonged lockdowns, media coverage began to warn of complacency, and a possible "second wave". The effects on national economies were debated on equal terms with public health themes, to the extent that they were presented as alternatives. In Spain, the Spanish Red Cross announced a social emergency as unemployment and poverty rates rose. In mid-May, the discourse in the U.K. changed from a focus on public health to the economic crisis, with a forecasted drop of $14 \%$ in the annual gross domestic product (GDP), the largest since 1720. By May, media narratives in Italy had already shifted from the science of COVID-19 to the economic revival of the country. News on the European Union's Recovery Fund, an economic package to boost reopening of economies, dominated the headlines. In Mexico, the high poverty rates and rising unemployment led to people rebelling against lockdown measures. One popular media commentator called on listeners to "not believe the false information" from the health minister. Many people in social networks and WhatsApp chains talked about the disease not existing at all, and "COVID parties" were held to provoke infections. Similarly, in South Africa, constant media coverage of the economic misery brought about by the lockdown focussed on the inequalities and social fault lines in society. The South African government could only offer limited financial relief, and some argued that the government's biggest failures were not providing food for millions of destitute South Africans deprived of any means to earn an 
income, and abandoning the 9 million children left hungry as school-feeding schemes shut down.

The media in Kenya reported concerns about tuberculosis and HIV patients being neglected amid the COVID-19 focus. Kenya has an average HIV prevalence rate of $6 \%$ and is one of the six HIV high-burden countries in Africa. Other concerns were that 6000 children could die daily due to COVID-19, and there would be an increase in poverty levels among small scale farmers. In Australia, Germany and Kenya, experts began commenting publicly on the rising levels of domestic violence and suicide, and the psychological effects of social distancing. The rise in gender-based violence during the lockdown became a prominent public concern in South Africa as well. In Sweden, additional governmental funding was allocated to social services and womens' shelters to address an increase in domestic violence.

Phase 4: discussions about when and how get back to normality, if at all. As restrictions eased, media commentary turned to the future. Had society changed forever? In Australia, media commentary discussed whether the post-COVID society would be the same. Would more people work from home? How should the economy be re-booted? People commented on the benefits of lower levels of pollution as industry shut down. Should we fear another pandemic? How could we capture the benefits of isolation while recovering from the negatives? Should we design our cities differently? In Germany, the focus moved from infections to the "new normality", summer holidays, demonstrations, and avoiding a second wave of infections. In Spain, communication from experts focussed on the need for citizens to act responsibly in order to reach the "new normality" as soon as possible.

Alongside the changing media commentary related to the internal virus clock, a number of significant themes relevant to science communication arose. These are situated within political, social and cultural conversations and debates.

\section{Q2: COVID-19 science communicators as media stars}

One reflection that resonated with us all was our observation that in many countries communicators rose to prominence (and in some cases, even stardom) between March and May 2020. These included media personalities, individual scientists, health and medical officers, and health ministers. Media personalities received high profiles and large followings in some countries. In Australia, a veteran medical reporter with the Australian Broadcasting Corporation (ABC), Norman Swan, co-created a new programme, Coronacast. His podcast answered questions about COVID-19 and broke the latest news and research. It sought to clarify confusing messages from government, especially on "social isolation" and other restrictions. Swan quickly became the most trusted expert on the pandemic.

Specific scientists reached prominence in the media as COVID-19 spokespeople in other countries as well. The German virologist Christian Drosten used a podcast to achieve a high profile. In South Africa, a 51-member committee comprised of leading (mostly health) scientists guided the government's COVID-19 response. The committee chair, Salim Abdool Karim, became the public face of science during the crisis [Joubert, 2020]. He repeatedly emphasised that the lockdown would 
achieve no more than to "flatten the curve", thereby buying time for the health system to prepare for the unavoidable surge in cases that would follow.

For Australia, Canada, Kenya, Spain and Sweden, the government's chief health or medical officers became prominent spokespeople, often reporting on scientific modelling and the shape of the curve. In Mexico, the health undersecretary, Hugo López-Gatell, played a leading role. López-Gatell is an epidemiologist and infectious disease expert, and his profile as a cordial medical doctor-scientist-civil servant on the scientific evidence generated public confidence. He was seen to be pleasant, trustworthy, and able to explain the science well. López-Gatell was backed up by daily government media briefings, including natural and social science specialists who explained national policy by presenting graphic evidence. However, many scientists and medical doctors have criticised his epidemiological approach and the perceived political bias of his discourse.

In India, the Kerala government's health minister, KK Shailaja, was one of the media stars in the early phase of the pandemic when the state was among the first to flatten the curve in India. In Spain, Fernando Simón, the epidemiologist responsible for the ministerial Coordination Centre for Health Emergencies, frequently appeared in the media, sometimes with the minister of health, other ministers, some senior military officers and often the prime minister. In Sweden, the state epidemiologist, Anders Tegnell of the Public Health Agency, quickly became the public authority on the virus and how it spread. Daily media briefings were broadcast live by public service radio and on the Internet.

The personal risks associated with the public prominence is demonstrated by the fate of the star epidemiologist Neil Ferguson in the U.K.; he resigned from his official role after he was caught breaking lockdown, which he had strongly advocated for. His resignation came at a convenient time for the government as they prepared to unlock restrictions.

\section{Q3: Shifting debates about science}

We found that debates quickly shifted across countries. The themes of these debates were often similar across countries, although happening at different times according to the virus's internal clock.

Many of the initial debates focussed on the degree of lockdown or physical isolation required. In the U.K., early debates were about government strategies, particularly on "herd immunity". In mid-March, the Sunday Times reported on "10 days that shook Britain", including internal government struggles over the "contain, delay and herd immunity" strategy. In mid-April, expert commentators with the Lancet launched an attack on government policy for being "late and wrong".

In Australia, where the science was broadly accepted, a bipartisan national cabinet was formed, and policy became a matter of political consensus. This bipartisan approach has endured, although there have been jurisdictional squabbles regarding the closing of state borders, and the opening of schools. In Spain, some scientists publicly criticised the level of action being taken and called for tighter restrictions and more testing. 
Public debate has occurred among scientists about the use of models and the numbers generated. In Sweden, an article signed by 22 scientists was published in mid-April in Dagens Nyheter, the most respected daily newspaper in Sweden. It criticised and questioned the Swedish strategy, based on the number of deaths per million inhabitants. The group included several emeriti, medical doctors and expert authors. These 22 scientists were cited widely in the press, especially in the tabloids, as they were criticising the strategy of the Public Health Authority. However, they were not considered by the experts to be the leading scientists in their fields.

A common debate was on the efficacy of face masks to stop the spread of COVID-19. In Kenya, the debate focussed on the most effective masks to use. In Spain, videos and infographics sought to explain the protective capacity of various masks and social media promoted tutorials on how to make your own masks. In the U.K. and Germany, experts disagreed about the benefits of wearing masks. In Australia, community members were urged to leave face masks for the medical professionals who needed them the most.

There was also debate about potential cures. In his April address to the nation, the Indian prime minister lauded India's efforts in distributing medicines to different parts of the world, including the anti-malarial drug hydroxychloroquine. Even as its effectiveness was being debated by the global scientific community, the Indian Council of Medical Research continued to maintain its stance that this drug could be administered to frontline health workers and published a report recommending this.

The use of technology to contact and trace people was another source of debate, with critics concerned about privacy issues. In Australia, a tracking app for phones, COVIDSafe, launched in late April, was downloaded by six million Australians by May 26, despite doubts about the efficacy of the app in tracking infections and privacy issues. Germany, Italy and India were also concerned about privacy issues related to a tracing app.

Uncertainty about easing restrictions was a key theme in countries that managed to flatten or even bend the curve. In Italy, in mid-April, Professor Walter Ricciardi, the Italian WHO representative, warned of a second wave which could be worse than the first. The Italian prime minister accepted this and extended social distancing measures for several months. As cases decreased sharply in Germany, the biggest tabloid newspaper (Bild) publicly criticised studies by Drosten (a virologist, prominent in the media), citing critical statements made by other scientists. This led to a public debate about science and scientific uncertainty, with implications for the opening of schools.

As the economic impacts were increasingly felt, protests against restrictive measures increased. In Mexico, with a surge of cases and confusing and contradictory messages, there was rising violence, indignation and mistrust. Despite increasing infections, restrictions were eased towards the end of May. It is difficult for the government to show scientific evidence for such decisions and predictive models were mentioned in daily press releases, but not explained.

In South Africa, there was a growing rift between prominent scientists calling for an end to the lockdown and the health minister who refused to budge. Amid concerns 
about secrecy and incompetence in the government's handling of the crisis, claims mounted that the COVID-19 threat was overstated and would be overshadowed by dire societal costs and irreparable economic damage. Tensions were further heightened by growing suspicions that the government was hiding behind science, but really wanted to harness the crisis for political gain, in particular to collapse the so-called "white economy" to allow drastic economic reforms.

\section{Q4: Assessing people's attitudes}

As a group reflection, we saw an interesting convergence in people's attitudes across countries. As concerns about the pandemic rose, and with the possibility of lockdowns, the media played to public fears about shortages and people started hoarding essential goods. A common concern was the lack of toilet paper. Media reported fights breaking out in supermarkets in Australia, and panic buying in Canada. Governments responded by issuing media statements to reassure people that there were no shortages in supplies of consumer goods.

Initially, public trust in governments rose in most countries as politicians responded to scientific evidence and acted to contain the pandemic. The approval rating of the Italian Prime Minister, Giuseppe Conte, soared after the government introduced a nationwide lockdown. In Australia, trust in all government leaders increased as they responded to expert advice, although surveys showed the public still trusted medical scientists more than politicians. This raised a question: how could politicians who unquestioningly accept medical advice on COVID-19, confidently ignore scientific advice on climate change? The inaction of policymakers on climate change has been a particularly vexing question for Australian science communicators. Despite uncertain scientific predictions and restrictions on constitutional rights, surveys showed that Germans were happy with how their government handled the crisis and trust in science rose sharply.

By contrast, there was less support for government policies in Spain, Mexico, South Africa and the U.K. A study in Spain found that almost half of the interviewees had little trust in the current or alternative governments to manage the pandemic. In South Africa, public support frayed as more evidence of government infighting and power grabbing surfaced and South Africans were increasingly dismayed by the heavy-handed (sometimes brutal) enforcement of lockdown regulations. In the U.K., there was ongoing public concern about the government's slowness to act, and a majority disapproved of government by mid May. Subsequently, there was concern that the government might be trying to hide behind the evidence by saying: "we only followed the scientists". Was all advice considered? Is the government avoiding making decisions by hiding behind the science? Trust in science was stable or even increased in the U.K., in sharp contrast to a Conservative government minister's earlier claim (during the Brexit debate in 2016) that "people in this country have had enough of experts". Science was seen as legitimate, although there was public concern about over reliance by government on particular types of evidence.

However, over time the initial public trust in the governments' abilities to manage the pandemic, began to decline and gave way to scepticism and denial. The Swedish NGO Vetenskap \& Allmänhet ("Science and Public") carried out public 
surveys in March, April and May to look at changes in trust in various groups of professionals. The mid-May survey showed a considerable decrease in public trust in scientists and politicians compared to the end of April. Peoples' perception was that researchers generally seemed to agree less as time went by. In late May, questions were raised about whether the "trust-in-people" policy really served Sweden well, and accountability was requested by the political opposition.

\section{Q5: Anxiety, conspiracy theories and misinformation}

Conspiracy theories seem to be most prominent at the height of a pandemic, when anxiety and uncertainty are high. The most common conspiracy theory circulating, especially in western democracies, was the mythical link between $5 \mathrm{G}$ and COVID-19 that had two things in common: features in media reporting: headaches and China. This theory led to public demonstrations in several countries. In the U.K., 5G antennas were vandalised. In Germany and Spain, fake news spread via WhatsApp claimed a connection between taking ibuprofen and severe COVID-19. Media specialising in fact-checking sprung up in response to such claims.

In Italy, after a long period of lockdown, towards the end of May, neo-fascist groups demonstrated on the streets of big cities and declared COVID-19 a conspiracy, while venting anti-establishment anger. Around the same time, Alberto Zangrillo, the head of the general anaesthesia and intensive care unit at the San Raffaele Hospital in Milan, made headlines in a TV interview when he claimed that the virus was all but non-existent from the clinical point of view.

The conspiracies and misinformation played out somewhat differently in developing countries, and often on social media (especially Facebook and WhatsApp). In Kenya, as the number of COVID-19 cases rose, Kenyans were encouraged by the state to access the Google $4 \mathrm{G}$ network to enable working from home and home schooling for children, despite rumours that the network was linked to a plan to control people.

In Mexico, groups and movements on social media expressed their disbelief in the virus, seeing it as a government invention. Some used social media to communicate their view that COVID-19 was transmitted by $5 \mathrm{G}$ antennas, and that doctors stole fluid from patients' knees to finance such antennas.

Fake news regarding vaccine trials or "expert" guidelines on disease prevention circulated widely in Indian social media. South Africa had its share of coronavirus misinformation and fake news, ranging from claims that test kits were intentionally contaminated with the virus, to conspiracy theories about the involvement of Bill Gates in creating and spreading the disease.

\section{Q6: Unique features in particular countries}

Each country dealt with the pandemic according to its own cultural context and challenges. For Australians, reeling from unprecedented summer bushfires, COVID-19 was another blow to society and the economy. The images of burnt koalas during the bushfires were replaced with a grim black humour reminder to maintain social distancing of 1.5 metres - or about four koalas. Kenyans 
wondered what other calamities might befall the country alongside ongoing floods and a locust invasion. Open-air markets were avoided by the majority of the population as potential sites for infection. In the U.K., poor pandemic preparation and the poor government response was linked to distractions associated with government policy's exclusive focus on Brexit.

In Spain, medical doctors and nurses made intensive use of social media to show their poor working conditions. They attributed this situation to 10 years of severe restrictions to the public health budget.

In India, the prime minister infused a mix of science, technology, mythology and culture in his televised addresses to the nation and in his hugely popular monthly radio programme "Mann ki baat" (roughly translated as "Inner thoughts"). His March address used mythology to convey the seriousness of the disease and the need to stay home and restrict the movement of people. Acknowledging the hardships, especially of the poor, he defended the government's decision to implement strict lockdown measures, saying that Indian traditional wisdom suggests "that an illness and its scourge should be nipped in the bud itself". In his April address, he asserted the importance of India's ancient traditions such as yoga and Ayurveda, important measures to boost immunity. He exhorted people to follow the guidelines issued by the AYUSH department (created specifically to promote traditional and alternative Indian schools of medicine and wellness).

Religion was a key COVID-19 theme of reference in Kenya, India and Mexico, alongside scientific and expert facts. In Kenya, national prayers were held across the country, even as places of worship were considered to be potential super-spreaders of the disease. In Mexico, views were expressed in the media and social media that it was better to pray and trust in God or the saints, than to stop working due to lockdown measures. There was a growing polarisation between those who trusted the Mexican government and health and scientific institutions, and those who mistrusted them.

\section{Concluding} remarks
This paper presents a descriptive account of science-society interactions as they emerge, evolve and recede in 11 countries in the early months of the COVID-19 pandemic. We pooled individual reflections, informed by autoethnographic techniques, on how science and health research entered public discourse, and how themes evolved over time in the media. Our reflections indicate that science communication through the media played a critical role in all countries: from informing of the symptoms of the virus to the more philosophical discussions about a changed future that happened in some countries as they "bent the curve" with decreasing infection rates. The cultural authority of science for the majority of the countries rose or was maintained during the first two phases of our study period. Science communicators of various types gained prominence in this period and scientists and politicians visibly worked closely together. However, when restrictions were eased and arguments increased about possible actions to restart failing economies, trust in science reduced in some countries and for some segments of society. Public debates, common to many countries, focussed on the efficacy of masks, potential cures and possible vaccines. Media reporting often highlighted disagreement among experts and, along with various conspiracy theories, may have served further to reduce trust in science. 
As a mirror to science and society relationships, this paper provides a rich but subjective reflection of the first 10 weeks of the pandemic. The individual observations of 12 science communication scholars from 11 different countries differed according to our differing cultural contexts. We have refrained from prematurely drawing conclusions as the situation continues to evolve. Rather, we provide a useful method for data collection and comparative analysis under restricted movement conditions, and a snapshot of a particularly important period in history. Clearly, there are limitations in our approach. We do not claim that this project is globally representative or that it encompasses all of the science and society themes associated with the first 10 weeks of the pandemic. We are a group of researchers from a diversity of countries and cultures across the world who were interacting on another project when the changing scenario prompted us to take note of a situation which was of great interest to our community. As an early account of the pandemic's first few months, informed by methods using autoethnographic techniques, we believe our reflections offer insights into the wider discourse about the role of science communication in various phases of the pandemic. We continue to maintain our diaries and meet online to share our reflections and collaborate. We will further investigate the material we report on here and combine our insights from these personal diaries with long-term media tracking in each country to compare science and society approaches to the pandemic.

Acknowledgments

We would like to acknowledge the support of the Rockefeller Foundation and the Bellagio Centre in bringing researchers associated with this study together to investigate science-society relationships in diverse regional and cultural contexts.

\section{References}

Adams, T. E., Ellis, C. and Jones, S. H. (2017). 'Autoethnography'. In: The international encyclopedia of communication research methods. Ed. by J. Matthes, C. S. Davis and R. F. Potter. Hoboken, NJ, U.S.A.: John Wiley and Sons, pp. 1-11. https://doi.org/10.1002/9781118901731. iecrm0011.

Allgaier, J. (2011). 'Who is having a voice? Journalists' selection of sources in a creationism controversy in the UK press'. Cultural Studies of Science Education 6 (2), pp. 445-467.

Anderson, A. A., Brossard, D. and Scheufele, D. A. (2010). 'The changing information environment for nanotechnology: online audiences and content'. Journal of Nanoparticle Research 12 (4), pp. 1083-1094. https://doi.org/10.1007/s11051-010-9860-2.

Andreouli, G. E., Gaskell, G. and Valsiner, J. (2015). Cambridge handbook of social representations. Cambridge, U.K.: Cambridge University Press. https://doi.org/10.1017/CB09781107323650.

Austin, L., Fisher Liu, B. and Jin, Y. (2012). ‘How audiences seek out crisis information: exploring the social-mediated crisis communication model'. Journal of Applied Communication Research 40 (2), pp. 188-207. https://doi.org/10.1080/00909882.2012.654498.

Bauer, M. W. and Gaskell, G. (1999). 'Towards a paradigm for research on social representations'. Journal for the Theory of Social Behaviour 29 (2), pp. 163-186. https://doi.org/10.1111/1468-5914.00096. 
Bauer, M. W., Gylstorff, S., Madsen, E. B. and Mejlgaard, N. (2019). 'The Fukushima accident and public perceptions about nuclear power around the globe - a challenge \& response model'. Environmental Communication 14 (4), pp. 505-526. URL: $10.1080 / 17524032.2018 .1462225$.

Bauer, M. W. (2015). 'On (social) representations and the iconoclastic impetus'. In: The Cambridge handbook of social representations. Ed. by G. Sammut, E. Andreouli, G. Gaskell and J. Valsiner. Cambridge, U.K.: Cambridge University Press, pp. 43-63. https://doi.org/10.1017/cbo9781107323650.006.

Bauer, M. W., Pansegrau, P. and Shukla, R. (2018). The cultural authority of science: comparing across Europe, Asia, Africa and the Americas. Abingdon, U.K.: Routledge. https://doi.org/10.4324/9781315163284.

Brossard, D. (2013). 'New media landscapes and the science information consumer'. Proceedings of the National Academy of Sciences 110 (Supplement 3), pp. 14096-14101. https://doi .org/10.1073/pnas.1212744110. PMID: 23940316.

Brossard, D. and Schefeule, D. A. (2013). 'Science, New Media and The Public'. Science 339 (6115), pp. 40-41. https://doi.org/10.1126/science.1232329.

Bryman, A. (2012). Social research methods. 4th ed. Oxford, U.K.: Oxford University Press.

Bucchi, M. and Saracino, B. (19th April 2020). 'Italian citizens and COVID-19: one month later - April 2020'. Public Understanding of Science Blog.

URL: https://sagepus .blogspot.com/2020/04/italian-citizens-and-covid -19-one-month.html.

Camus, A. (1947). La peste. Paris, France: Éditions Gallimard.

Collinson, S., Khan, K. and Heffernan, J. M. (2015). 'The effects of media reports on disease spread and important public health measurements'. PLOS ONE 10 (11), e0141423. https://doi.org/10.1371/journal.pone.0141423.

Dingwall, R., Hoffman, L. M. and Staniland, K., eds. (2013). Pandemics and emerging infectious diseases: the sociological agenda. Hoboken, NJ, U.S.A.: John Wiley and Sons. https://doi .org/10.1002/9781118553923.

Dudo, A. D., Dahlstrom, M. F. and Brossard, D. (2007). 'Reporting a potential pandemic: a risk-related assessment of avian influenza coverage in U.S. newspapers'. Science Communication 28 (4), pp. 429-454. https://doi.org/10.1177/1075547007302211.

Ellis, C., Adams, T. E. and Bochner, A. P. (2011). 'Autoethnography: an overview'. Forum Qualitative Sozialforschung / Forum: Qualitative Social Research 12 (1), 10. https://doi.org/10.17169/FQS-12.1.1589.

Entman, R. M. (1993). 'Framing: toward clarification of a fractured paradigm'. Journal of Communication 43 (4), pp. 51-58. https://doi.org/10.1111/j.1460-2466.1993.tb01304.x.

Fang, F. (2020). Wuhan diary: dispatches from a quarantined city. New York, NY, U.S.A.: Harper Collins.

Fogarty, A. S., Holland, K., Imison, M., Blood, R. W., Chapman, S. and Holding, S. (2011). 'Communicating uncertainty - how Australian television reported H1N1 risk in 2009: a content analysis'. BMC Public Health 11 (1), 181. https://doi.org/10.1186/1471-2458-11-181.

Franks, B., Bangerter, A. and Bauer, M. W. (2013). 'Conspiracy theories as quasi-religious mentality: an integrated account from cognitive science, social representations theory and frame theory'. Frontiers of Psychology 4, 424 . https://doi.org/10.3389/fpsyg. 2013.00424. 
Franzosi, R. and Vicari, S. (2018). 'What's in a text? Answers from frame analysis and rhetoric for measuring meaning systems and argumentative structures'. Rhetorica 36 (4), pp. 393-429. https: //doi .org/10.1525/rh.2018.36.4.393.

Garrett, L. (1994). The coming plague - newly emerging diseases in a world out of balance. New York, NY, U.S.A.: Penguin Books.

German National Academy of Sciences (2017). Social media and digital science communication analysis and recommendations for dealing with risks and opportunities in a democracy. Munich, Germany: German National Academy of Sciences. URL: https://en.acatech.de/publication/social-media-und-di gitale-wissenschaftskommunikation-analyse-und-empfehlungen-zum-umga ng-mit-chancen-und-risiken-in-der-demokratie/.

González, G. D. C., Hoyos, J. R. C. and Méndez, M. G. C. (2011). ‘Las metáforas de la influenza humana A (H1N1) en México: el escenario nacional al descubierto. Una aproximación a través de la prensa mexicana'. Comunicación y sociedad 16, pp. 105-132. URL: http://www.scielo.org.mx/scielo.php?script=sci_artte xt\&pid=S0188-252X2011000200005.

Gottlieb, M. and Dyer, S. (2020). 'Information and disinformation: social media in the COVID-19 crisis'. Academic Emergency Medicine 27 (7), pp. 640-641. https://doi.org/10.1111/acem.14036.

Graham, T., Bruns, A., Zhu, G. and Campbell, R. (2020). Like a virus: the coordinated spread of Coronavirus disinformation. Canberra, ACT, Australia: The Australia Institute. URL: https://eprints.qut.edu.au/202960/1/P904_Li ke_a_virus_COVID19_disinformation_Web_.pdf.

Gugsa, F., Karmarkar, E., Cheyne, A. and Yamey, G. (2016). 'Newspaper coverage of maternal health in Bangladesh, Rwanda and South Africa: a quantitative and qualitative content analysis'. BMJ Open 6 (1), e008837. https://doi.org/10.1136/bmjopen-2015-008837.

Hewitt, E. (2017). 'Building bridges: the use of reflective oral diaries as a qualitative research tool'. International Journal of Research $\mathcal{E}$ Method in Education 40 (4), pp. 345-359. https://doi.org/10.1080/1743727x.2015.1114601.

Hilton, S. and Smith, E. (2010). 'Public views of the U.K. media and government reaction to the 2009 swine flu pandemic'. BMC Public Health 10 (1), 697. https://doi.org/10.1186/1471-2458-10-697.

Holmes, B. J., Henrich, N., Hancock, S. and Lestou, V. (2009). 'Communicating with the public during health crises: experts' experiences and opinions'. Journal of Risk Research 12 (6), pp. 793-807. https://doi .org/10.1080/13669870802648486.

Joubert, M. (2020). 'From top scientist to science media star during COVID-19South Africa's Salim Abdool Karim'. South African Journal of Science 116 (7/8), 8450. https://doi.org/10.17159/sajs.2020/8450.

Kenten, C. (2010). 'Narrating oneself: reflections on the use of solicited diaries with diary interviews'. Forum Qualitative Sozialforschung / Forum: Qualitative Social Research 11,16, p. 2. https://doi.org/10.17169/FQS-11.2.1314.

Lapadat, J. C. (2017). 'Ethics in autoethnography and collaborative autoethnography'. Qualitative Inquiry 23 (8), pp. 589-603. https://doi.org/10.1177/1077800417704462.

Mandeville, K. L., O’Neill, S., Brighouse, A., Walker, A., Yarrow, K. and Chan, K. (2014). 'Academics and competing interests in H1N1 influenza media reporting'. Journal of Epidemiology and Community Health 68 (3), pp. 197-203. https://doi.org/10.1136/jech-2013-203128. 
McCombs, M. E. (2004). Setting the agenda: the mass media and public opinion. Cambridge, U.K.: Polity.

McCombs, M. E. and Shaw, D. L. (1972). 'The Agenda-Setting Function of Mass Media'. Public Opinion Quarterly 36 (2), pp. 176-187. https://doi.org/10.1086/267990.

Moscovici, S. (1961). La psychanalyse, son image et son public. Paris, France: Presses Universitaires de France.

Patterson, A. (2005). 'Processes, relationships, settings, products and consumers: the case for qualitative diary research'. Qualitative Market Research: An International Journal 8 (2), pp. 142-156. https://doi.org/10.1108/13522750510592427.

Sammut, G., Andreouli, E., Gaskell, G. and Valsiner, J. (2015). The Cambridge handbook of social representations. Cambridge, U.K.: Cambridge University Press. https://doi.org/10.1017/CB09781107323650.

Sandman, P. M. (2009). 'Pandemics: good hygiene is not enough'. Nature 459 (7245), pp. 322-323. https://doi.org/10.1038/459322a.

Scheufele, D. A. (2014). 'Science communication as political communication'. Proceedings of the National Academy of Sciences 111 (4), pp. 13585-13592. https://doi.org/10.1073/pnas.1317516111.

Smith, R. D. (2006). 'Responding to global infectious disease outbreaks: lessons from SARS on the role of risk perception, communication and management'. Social Science \& Medicine 63 (12), pp. 3113-3123. https://doi.org/10.1016/j.socscimed.2006.08.004.

United Nations Department of Global Communications (2020). UN tackles 'infodemic' of misinformation and cybercrime in COVID-19 crisis. URL: https: // www .un .org/en/un-coronavirus-communications-team/un-tackling- \%E2\%80\%98 infodemic\%E2\%80\%99-misinformation-and-cybercrime-covid-19.

Wagner, W. and Hayes, N. (2005). Everyday discourse and common sense: the theory of social representation. Basingstoke, U.K.: Palgrave Macmillan.

Wall, S. (2008). 'Easier said than done: writing an autoethnography'. International Journal of Qualitative Methods 7 (1), pp. 38-53. https://doi.org/10.1177/160940690800700103.

Jenni Metcalfe is director of Econnect Communication, established in 1995. As a science communicator for more than 30 years, she has worked as a journalist, practitioner, university lecturer and researcher. Jenni is a foundation member of the Australian Science Communicators and has been a member of the scientific committee of the International Public Communication of Science and Technology (PCST) Network since 1996. Jenni is a Campus Visitor at the Australian National University's Centre for Public Awareness of Science.

E-mail: jenni@econnect.com.au.

Michelle Riedlinger (Ph.D., University of Queensland, 2005) is a senior lecturer in the School of Communication at the Queensland University of Technology, Australia. Her research focuses on public engagement in science and technology, and environmental and health science writing. She is currently investigating science-society relationships and public risk assessment in online science communication environments in Canada and Australia. She is Secretary of the Public Communication of Science and Technology (PCST) Network. E-mail: michelle.riedlinger@qut.edu.au. 
Martin W. Bauer read Psychology and Economic History (Bern, Zurich, London), and is Professor of Social Psychology (London School of Economics and Political Science, LSE). He was Editor-in-Chief of Public Understanding of Science (2009-2016), and he investigates 'common sense' in comparative perspective and its relationship to global techno-scientific developments. Recent books include: Atom, Bytes \& Genes - Public Resistance and Techno-Scientific Responses, NY, Routledge, 2015; and The Cultural Authority of Science - comparing across Europe, Asia, Africa, and the Americas, London, Routledge, 2019. E-mail: M.Bauer@lse.ac.uk.

Anwesha Chakraborty is a postdoctoral fellow at the Department of Political and Social Sciences at University of Bologna. Her research interests include public understanding of science; science and technology policies; digitalization and society; and gendered use of ICTs. E-mail: anwesha.chakraborty3@unibo.it.

Toss Gascoigne is a visiting fellow at the Centre for Public Awareness of Science at the ANU, Australia. He is interested in the interface between science and policy and has published on training scientists in communication, on whether the field is a discipline, and science advocacy. He is currently editing a book charting the emergence of modern science communication in 39 countries.He is a former president and life member of both Australian Science Communicators and the PCST Network. E-mail: director@tossgascoigne.com.au.

Lars Guenther (Ph.D., 2015, at Friedrich Schiller University Jena, Germany) is Senior Research Associate in the Cluster of Excellence on "Climate, Climatic Change, and Society" (CliCCS) at University of Hamburg, and Extraordinary Senior Lecturer at the Centre for Research on Evaluation, Science and Technology (CREST) at Stellenbosch University in South Africa. He is interested into public perceptions of (controversial) science, science and health journalism, as well as the public communication about risks and scientific (un)certainty.

E-mail: lars.guenther@uni-hamburg.de.

Marina Joubert is a science communication researcher at the South African Research Chair in Science Communication \& Centre for Research on Evaluation, Science and Technology, Stellenbosch University, South Africa. She teaches on an MPhil programme and presents online courses focused on science communication in an African context. Her research interests focus on scientists' role in public communication of science, online interfaces between science and society and the use of visual tools to engage the public with science.

E-mail: marinajoubert@sun.ac.za.

Margaret Kaseje is professor and Director of Programs and Research at the Tropical Institute of Community Health and Development in Kisumu, Kenya. She is also the Vice President of the Association of Schools of Public Health in Africa (ASPHA). E-mail: mkaseje@gmail.com.

Susana Herrera-Lima is a professor in ITESO University, México, where she addresses the sociocultural perspective of science communication in teaching and research projects. She works in the intersection between public communication of science and environmental communication. She is an adviser for the development of social problems-driven projects in science and environment communication with 
citizen participation, working with civil society organizations, scientists and communicators. The is a member of the Public Communication of Science and Technology (PCST) Network. E-mail: shl@iteso.mx.

Gema Revuelta (MD, Ph.D.). Graduated in Medicine, Ph.D. and master's degree in Science Communication. She has been working on health communication research and assessment for more than 25 years. Director of the Studies Centre on Science, Communication and Society from Universitat Pompeu Fabra (Barcelona), associated professor of Science Communication at the same university. Director of the master's degree on Science, Health and Environmental Communication at Barcelona School of Management - UPF. Deputy-director of the Spanish Science Communication Association (AECC). E-mail: gemma.revuelta@upf.edu.

Jan Riise has spent over 25 years at the interface between science, society and policy, and he is now working as Engagement Manager at Gothenburg Centre for Sustainable Development, a joint platform for sustainability research between University of Gothenburg and Chalmers University of Technology. Life-time member of PCST, former president of European Science Events Association. E-mail: jan.riise@chalmers.se.

Bernard Schiele Ph.D. is a Professor of Communications in the Faculty of Communication at the University of Quebec at Montreal (Canada). He teaches and lectures frequently in North America, Europe and Asia, and has been working for a number of years on the socio-dissemination of S\&T. He is a member of several national and international committees. He is also a founding member and current member of the Scientific Committee of the PCST network.

E-mail: schiele.bernard@uqam.ca.

\section{How to cite}

(C) The Author(s). This article is licensed under the terms of the Creative Commons Attribution - NonCommercial - NoDerivativeWorks 4.0 License.

ISSN 1824-2049. Published by SISSA Medialab. jcom.sissa.it 